First publ. in: Phytopathologische Zeitschrift 94 (1979), pp. 89-91

Biologische Bundesanstalt für Land-und Forstwirtschaft, Institut für Viruskrankbeiten der Pflanzen, Braunschweig, und Institut für Pflanzenpatbologie und Pflanzenschutz der Georg-August-Universität Göttingen

\title{
Quantitative Serological Estimation of a Hyperparasite: Detection of Verticillium lecanii in Yellow Rust Infected Wheat Leaves by ELISA
}

\author{
By \\ R. Casper and K. Mendgen \\ With one figure
}

Received November 27, 1978

Detecting the presence and amount of a fungus in leaf tissue, especially when it is suspected that other fungi are present, is quite difficult. Culture methods can be unreliable because a few spores of a fast growing fungus may overgrow other fungi within a few days (e.g. MCKENZIE and Hudson 1976). Methods which measure the chitin content of fungal walls cannot differentiate between fungi; in addition, recent evidence suggests that there is no direct correlation between the amount of fungal hyphae and the amount of chitin (Mayama et al. 1975).

Serological tests, because of their high specificity could be a passible solution for these problems. We therefore used the technique of enzyme-linked immunosorbent assay (EIISA), as modified for the detection and identification of plant viruses by CLARK and ADAMS (1977). Since ELISA enables quantitative measurement of antigen we used it to estimate Verticillium lecanii at different stages of infection in leaves of wheat heavily infected with yellow rust (Puccinia striiformis).

\section{Material and Methods}

To prepare an antiserum with maximum specificity Verticillium lecanii was cultured in $0.5 \%$ malt solution for 10 days, after which the mycelium was harvested, washed in water and freeze-dried. The freeze-dried powdered mycelium was resuspended in 5 volumes of water (w/v), emulsified with Freund's complete adjuvant (Difco), and injected intra- 
muscularly into a rabbit. The rabbit was bled four weeks after the injection and the $\gamma-$ globulin fraction of a portion of the antiserum prepared for ELISA according to CLARK and ADams (1977). In agar gel tests (Ouchterlony) the antiserum showed a specific titer of $1: 16$ to Verticillium lecanii, but the precipitation line was weak and diffuse.

For use in the ELISA test the coating and enzyme-labelled $\gamma$-globulin preparations were both diluted 1:500. ELISA values were obtained by measuring absorbance at $405 \mathrm{~nm}$.

Whear cv. Michigan Amber was raised in a growth chamber at $15^{\circ} \mathrm{C}$ with fluorescent light (2000 lux) $16 \mathrm{~h} /$ day. After 10 days, the plants were inoculated with yellow rust ( $P_{\text {ucci- }}$ nia striiformis West., race $37 \mathrm{E} 132$ ). After 14 days, when the rust was sporulating the leaves were sprayed with a suspension of Verticillium lecanii spores, isolated from a rust pustule collected in the field. Samples of these leaves were taken 7 days later for the serological tests.

Incubating infected plants maintained in growth chambers at different humidities influenced the development of V.lecanii in the rust pustules. At $80 \%$ humidity, no V.lecanii was observed, however Verticillium hyphae could be detected by microscopical examination in a few pustules at $90 \%$ and at $95 \%$ in all rust pustules. To measure the amount of Verticillium hyphae in these leaves, $200 \mathrm{mg}$ of leaf tissue was freeze-dried and subjected to the ELISA test.

\section{Results and Discussion}

In Figure 1 the condition of the leaf samples at time of harvest is shown and correlated to the results obtained in ELISA tests. Positive reactions were obtained with leaf samples containing $V$. lecanii (Figs. 1c and d) but not with the control uninfected wheat leaf or Puccinia striiformis infected wheat leaf

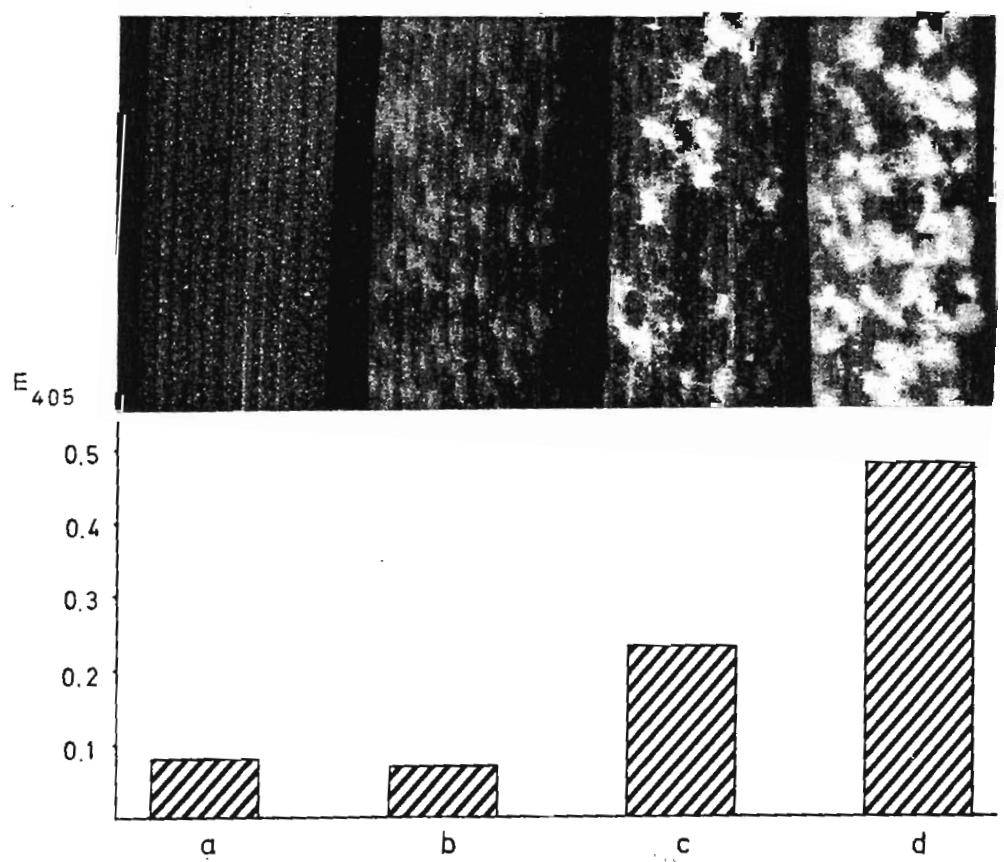

Fig. 1. ELISA extinction values for wheat leaf extracts: (a) uninfected wheat leaf; (b) yellow rust infected wheat leaf; (c) wheat leaf with yellow rust and Verticillium lecanii grown at $90 \%$ humidity and (d) grown at $95 \%$ humidity 
samples. This shows that there is no immunological reaction between $P$. striiformis and the antiserum against $V$. lecanii.

The small amount of mycelium developed at $90 \%$ humidity, was enough to obtain an extinction value of 0.23 . In contrast at $95 \%$ humidity the larger amount of mycelium induced an extinction value of 0.48 . These data show that the ELISA technique is capable of quantitatively indicating the amount of $V$. lecanii in $P$. striiformis infected leaf tissue.

This is the first report of detection of fungal mycelium by ELISA. This technique may have a general usefulness for detecting fungal infections.

\section{Summary}

The ELISA technique enabled the quantitative serological determination of Verticillium lecanii in yellow rusted wheat leaves. Detection of V. lecanii was not affected by the presence of Puccinia striiformis in the same leaf.

\section{Zusammenfassung}

Quantitative serologische Bestimmung eines Hyperparasiten: Nachweis von Verticillium lecanii in gelbrost-infizierten Weizenblättern mit dem ELISA-Test

Mit dem ELISA-Test kann Verticillium lecanii in Gelbrost (Puccinia striiformis) befallenen Weizenblättern quantitativ bestimmt werden. Diese quantitative Bestimmung wird durch die Anwesenheit von P. striiformis nicht gestört.

We thank Dr. Eva Fuces for supplying the fungus isolates and helpful advice. Thanks are also due to the Deutsche Forschungsgemeinschaft for financial support.

\section{Literature}

ClARK, M. F., and A. N. ADAMS, 1977: Characteristics of the microplate method of the enzyme-linked immunosorbent assay (ELISA) for the detection of plant viruses. J. gen. Virol. 34, 475-483.

Mayama, S.,. D. W. Rehfeld-, and J. M. Daly, 1975: A comparison of the development of Puccinia graminis tritici in resistant and susceptible wheat based on glucosamine content. Physiol. Plant Path. 7, 243-257.

McKenzie, E. H. C., and H. J. Hudson, 1976: Mycollora of rust infected and non-infected plant material during decay. Trans. brit. Mycol. Soc. 66, 223-238.

Authors' addresses: R. CASPER, Institut für Viruskrankheiten der Pflanzen, Biologische Bundesanstalt; Messeweg 11/12, D-3300 Braunschweig (Germany), and K. MENDGen, Institut für Pflanzenpathologie und Pflanzenschutz, Universität Göttingen, Grisebachstraße 6, D-3400 Göttingen-Weende (Germany). 